\title{
Japan is first non-CERN contributor to LHC
}

Tokyo. Partly as a result of the Kobe earthquake, Japan's Ministry of Education, Science and Culture (Monbusho) has managed to surprise the world of high-energy physics with a quick decision to contribute $¥ 5$ billion (US\$60 million) towards the construction of Europe's Large Hadron Collider (LHC). Japan is the first foreign country not belonging to the European Laboratory for Particle Physics (CERN) to back the LHC.

The contribution in cash will be drawn from a supplementary budget of $¥ 2,726$ billion drawn up by the government in response to the Kobe disaster. The budget, which was approved by the cabinet last week and is expected to receive quick approval by Japan's parliament, the Diet, is primarily intended to finance reconstruction of the Kobe region and disaster prevention activities. But it also contains $¥ 320$ billion for information networks and science - including the budget for the LHC.

Christopher Llewellyn Smith, director general of CERN, said on Monday that he is "absolutely delighted" by the Japanese decision. He said he had been confident of a Japanese contribution after visiting Tokyo in March (see Nature 374, 103; 1995), but has been pleasantly surprised with both the speed at which the money has been found and its amount.

According to Llewellyn Smith, Japan's contribution is not itself sufficient to bring forward LHC's construction schedule. But he says it is a "great step forward".

The LHC is scheduled to reach its maxi- mum energy of $14 \mathrm{TeV}$ by 2008 in two phases of construction. But if CERN can raise about 600 million Swiss francs in nonmember contributions - about ten times the promised contribution from Japan construction could be completed in one phase by 2004.

Japan is prepared to consider further contributions "in the light of the development of cooperation between CERN and Monbusho, the progress of the LHC project, and contributions from other nonmember states", says a spokesman for the ministry. Kaoru Yosano, the minister of education, says that Japan took the lead in contributing in the hope that it "will accelerate international cooperation in the project".

But the United States has given no commitment so far that it will follow in Japan's footsteps. US high-energy physicists remain keen to support construction of the LHC following the demise of the Superconducting Super Collider, and the US Department of Energy (DoE) has expressed interest in supporting the LHC. But the department faces an uphill battle with Congress over its budget, and a US decision to enter formal negotiations on the LHC is not expected to be made until later in the year.

Shuji Orito, head of Tokyo University's International Center for Elementary Particle Physics, which participates in experiments on CERN's electron-positron collider LEP, describes the Japanese decision as a "great initiative" by Monbusho.

Hirotaka Sugawara, director general of the National Laboratory of High Energy Physics (KEK) in Tsukuba science city, is slightly more cautious, pointing out that there are "many problems that need to be solved". In particular, he says that Japan is hoping for observer status both on CERN's council and on other committees making decisions concerning the LHC.

A decision on this has not yet been made by CERN's council. But Llewellyn Smith is confident that a request for observer status would be looked on "very favourably", and is keen that Japan should consider some sort of new "associate status" to give it a "real voice" in CERN decisions.

$\mathrm{KEK}$ is developing some of the dipole magnets for the LHC. Following the funding decision, Sugawara says he expects his laboratory to work also on the quadrupole magnets for fine control of the proton beams.

But he wants European scientists to go to KEK and develop the magnets jointly. Japan, he says, "cannot be held responsible" for operation of the magnets at CERN. He is also keen that CERN should hire some Japanese scientists; until now, CERN has drawn its employees only from member states.

\section{Agency halts HIV survey in dispute over newborn data}

Washington. In a move that has surprised some of their closest advisers, the US Centers for Disease Control and Prevention (CDC) in Atlanta have suspended a \$10.5million surveillance study designed to track HIV infection in women, to avoid being forced by Congress to collect full details of HIV exposure in newborn children.

At a congressional hearing in Washington last week, Helene Gayle, acting director of CDC's national centre for prevention services, announced that Philip Lee, the assistant secretary for health, was asking all states to suspend such testing of newborns.

The hearing was held to discuss a bill introduced by Gary Ackerman (Democrat, New York) requiring states to disclose the results of HIV tests to the legal guardians of babies tested this way. CDC's move has pulled the rug out from under the proposed legislation. But it has also prompted Ackerman to consider introducing a new bill requiring HIV testing for all US newborns.

CDC began its survey of HIV in childbearing women in 1988 as part of its efforts to track HIV infection in women by testing the blood of their newborns. With CDC's support, 45 states have been routinely testing samples of blood from newborns for HIV-1 antibodies, removing personal identifying information but retaining limited demographic data. The survey had no termination date, although its funding would have had to be renewed at the end of this year.

Ackerman introduced his legislation to lift the restrictions on the data being reported to $\mathrm{CDC}$, and to require that the legal guardians of all babies testing positively for HIV be notified and counselled. His goal is to enable prospective adoptive parents access to information on the HIV status of babies, and allow parents with infected babies to begin immediate treatment.

But although only 15 to 30 per cent of all babies born to infected mothers are themselves infected, virtually all test positive at birth, because of the presence of maternal antibodies to HIV in the bloodstream.

Suspending the study was "a bold move by CDC - they were boxed into a corner by the Ackerman bill," says Laura Morrison of the Treatment Action Group (TAG). "It was a compassionate decision in the interest of protecting the privacy of women being screened. 'Unblinding' the study would in effect make testing mandatory."

During the congressional hearing, Gayle pointed out that a recent study by the National Institutes of Health showed that maternal transmission of HIV can be drastically reduced through the administration of AZT during pregnancy.

Gayle said that CDC would like to see more infected women identified, counselled and treated before or during pregnancy, in order to reduce the risk of transmission to unborn infants. Newborn screening, says $\mathrm{CDC}$, is too little too late to prevent HIV transmission to children.

New CDC guidelines will be published next month calling for greater emphasis on prevention by encouraging counselling and voluntary screening of all pregnant women for HIV infection. A panel of experts is being set up to examine ways of promoting the new guidelines for prevention and treatment, and will evaluate the role of the HIV survey in that effort.

Nancy Touchette 